\title{
Review
}

\section{NEUTROPHIL TO LYMPHOCYTE RATIO: A TESTICULAR CANCER DIAGNOSTIC TOOL}

\author{
RELACIÓN NEUTRÓFILO-LINFOCITARIA: UNA \\ HERRAMIENTA DE DIAGNÓSTICO DEL CÁNCER \\ TESTICULAR
}

Jose Luis Bauza ${ }^{1 *}$, Antonio Tienza ${ }^{1}$, Riccardo Bertolo², Arnau Sabaté ${ }^{2}$, Jorge Guimerà ${ }^{1}$, ValentíTubau $^{1}$, Enrique Pieras ${ }^{1}$.

${ }^{1}$ Urology Department, Hospital Universitari Son Espases. Palma de Mallorca, Balearic Islands, Spain.

${ }^{2}$ Center for Laparoscopic and Robotic Surgery, Glickman Urological \& Kidney Institute, Cleveland Clinic, Cleveland, Ohio, United States.

\section{*Corresponding Author:}

Urology Department, Hospital Universitari Son Espases, floor 0, desk Q046, Carretera de Valldemossa 79, 07120 Palma, Balearic Islands, Spain.

Email: peplluis15@hotmail.com

Telephone: +34608688560

Received: 11 November 2019, Approved: 11 April 2020, Published: June 2020.

\begin{abstract}
Introduction: Neutrophil to lymphocyte ratio (NLR) has been recently involved in multiple steps of cancer development, including its progression and prognosis. Our primary objective was to evaluate the NLR's potential diagnostic value in testicular cancer. Our secondary objectives were to describe its role in pre-orchiectomy staging and to set an optimal diagnostic cut-off value for our testicular cancer cohort.

Materials \& methods: We retrospectively reviewed 80 testicular cancer patients between January 2005 and December 2018. Age, histopathological features and NLR were recorded. The other 86 men were included in the study as a control group, and their NLR was calculated. Data were analyzed by means comparison, Pearson correlation coefficient, and ROC curve analysis. Sensibility and 1specificity tables according to the minimum description length principle method was used to identify the optimal NLR cut-off value for testicular cancer diagnosis.

Results: Testicular cancer patient's mean age was 33.75 (19-51) years and the control group's mean age was 33.15 (20-50) years. NLR was found significantly higher in the testicular cancer group (2.62 \pm 1.56 vs. $1.37 \pm 0.53 ; \mathrm{p}<0.001)$. No correlation was observed between NLR and pre-orchiectomy AFP, hCG, and LDH (r-value: 0.08, 0.06 and 0.09, respectively). NLR was higher in patients with a
\end{abstract}


stage $>$ I $(3.3 \pm 1.39$ vs. $2.28 \pm 1.55 ; \mathrm{p}=0.014)$. The best NLR cut-off value for testicular cancer diagnosis was: 2.2 (sensibility: $76 \%$, specificity: $70 \%$, area under the curve: 0.802 ).

Conclusions: The NLR could be a useful tool in the testicular cancer diagnosis because itis higher in testicular cancer group and patients with higher stages of the disease. The NLR's optimal diagnostic cut-off value for our cohort is 2.2 .

\section{Resumen}

Introducción: La relación de neutrófilos a linfocitos (NLR) ha estado involucrada recientemente en múltiples pasos del desarrollo del cáncer, incluyendo su progresión y pronóstico. Nuestro objetivo principal era evaluar el valor diagnóstico potencial de la NLR en cáncer testicular. Nuestros objetivos secundarios fueron describir su papel en la estadificación previa a la orquiectomía y establecer un valor de corte de diagnóstico óptimo para nuestra cohorte de cáncer testicular.

Materiales y métodos: Revisamos retrospectivamente a 80 pacientes con cáncer testicular entre enero de 2005 y diciembre de 2018. Se registraron la edad, las características histopatológicas y la NLR. Los otros 86 hombres fueron incluidos en el estudio como grupo de control, y se calculó su NLR. Los datos se analizaron mediante comparación de medias, coeficiente de correlación de Pearson y análisis de curva ROC. Se utilizaron tablas de sensibilidad y 1-especificidad según el método del principio de longitud mínima de descripción para identificar el valor de corte óptimo de NLR para el diagnóstico de cáncer testicular.

Resultados: La edad media del paciente con cáncer de testículo fue de 33,75 (19-51) años y la edad media del grupo de control fue de 33,15 (20-50) años. NLR se encontró significativamente mayor en el grupo de cáncer testicular $(2.62 \pm 1.56$ vs. $1.37 \pm 0.53 ; \mathrm{p}<0.001)$. No se observó correlación entre NLR y pre-orquiectomía AFP, hCG y LDH (valor r: 0.08, 0.06 y 0.09 , respectivamente). NLR fue mayor en pacientes con una etapa $>$ I $(3.3 \pm 1.39$ vs. $2.28 \pm 1.55 ; \mathrm{p}=0.014)$. El mejor valor de corte de NLR para el diagnóstico de cáncer testicular fue: 2.2 (sensibilidad: $76 \%$, especificidad: 70\%, área bajo la curva: 0.802)

Conclusiones: El NLR podría ser una herramienta útil en el diagnóstico de cáncer testicular porque es mayor en el grupo de cáncer testicular y pacientes con etapas más altas de la enfermedad. El valor de corte de diagnóstico óptimo de la NLR para nuestra cohorte es 2.2.

Keywords: Neutrophil To Lymphocyte Ratio, Testicular Cancer, Diagnostic Test, Liquid Biopsy.

\section{Introduction}

Testicular cancer is a relatively rare disease, representing $1 \%$ of the neoplasms in males and $5 \%$ of the urological tumors [1,2]. Nevertheless, it is the most common solid malignancy affecting men between 15 and 35 years old [3]. Moreover, its importance among the industrialized Countries is increasing as the rate of disease recurrences has progressively risen during the last decades [4-7].

It is known that systemic inflammation processes play a critical role in many aspects related to cancer, such as tumor growth, disease progression, clinical presentation and prognosis [8]. Multiple mechanisms have been suggested 
and numerous markers of systemic inflammation have been described, including the $\mathrm{C}$ reactive protein, the platelets or leucocytes counts and the neutrophil to lymphocyte ratio (NLR) [9)].

Previous studies found the NLR a poor prognostic factor in either urological cancers (renal, prostatic, urothelial and penile) [10-13] or non-urological (colorectal, pancreatic, breast and contribution to the field, we conceived the present hepatic) [14-17]. Only a few groups have studied the role of the NLR in testicular cancer diagnosis $[18,19]$, with promising results. Thus, to give us a retrospective study. The purpose was to study the NLR as a diagnostic biomarker for testicular cancer patients. Secondary objectives were to describe its role in pre-orchiectomy staging and to set an optimal diagnostic cut-off value for our testicular cancer cohort.

\section{Materials \& methods}

Data of 166 men were retrospectively extracted. 80 of them were patients with a testicular cancer diagnosis who underwent a radical orchiectomy at our Institution between January 2005 and December 2018. Radical orchiectomy had been performed according to the guidelines recommendations [11]. Other 86 healthy men on whom a circumcision procedure was performed, were recruited as the control group.

The subjects' demographic, clinical data and complete blood count (CBC) were extracted. Pre-orchiectomy, the $\mathrm{CBC}$ was performed 5 to 7 days before the surgery. The NLR was calculated by dividing the absolute neutrophils count by the absolute lymphocytes count. Lactate dehydrogenase (LDH), alpha-fetoprotein (AFP), human chorionic gonadotropin (hCG) were determined pre-orchiectomy too.

Pathological variables, including histology, tumor size and stage (based on the 2009 TNM classification of the International Union Against Cancer) [20] were collected, together with tumor features suggesting occult metastatic disease [21,22] (seminomas: tumor size $>4 \mathrm{~cm}$ and rete testis invasion; non-seminomas: vascular/ lymphatic invasion, proliferation rate $>70 \%$, and percentage of embryonal carcinoma $>50 \%$ ).

It is known that several conditions and drugs (typically those with an immunosuppressant effect) can alter the white blood cell counts, thus modifying the NLR. In order to avoid this bias, we used the following exclusion criteria: patients with active/chronic infectious diseases, inflammatory diseases (such as Crohn disease, rheumatoid arthritis, lichen sclerosus...), immunosuppressant diseases (such as HIV), renal/liver insufficiency, diabetes mellitus, steroids or $\beta$-agonist treatments, hematologic diseases or other neoplasms which could also alter NLR values [23].

\section{Statistical analysis}

Descriptive analysis was performed calculating means and standard deviations for continuous variables, and frequencies and proportions for categorical ones. NLR was evaluated as a continuous variable. Comparisons between two groups were performed using the Student's t-tests. Pearson correlation coefficient was used to assess the correlation between pre-orchiectomy NLR and pre-orchiectomy tumor markers. Receiver operating characteristic (ROC) curve analysis was drawn for testicular cancer diagnosis. To identify the optimal cut-off values of the NLR to predict testicular cancer diagnosis, we used sensibility and 1-specificity tables according to the minimum description length principle method [24]. p-value $<0.05$ indicated statistical significance. Statistical analysis was performed using IBMC SPSS ${ }^{\circledR}$ Statistics v21.

\section{Results}

Clinico-pathological data of both study groups are summarized in table 1. 
Table 1. Clinical-pathological features

\begin{tabular}{|c|c|c|c|c|}
\hline & \multicolumn{2}{|c|}{ Testicular cancer group } & Control group & $P$ value \\
\hline & $(n=80)$ & & $(n=86)$ & \\
\hline Age (years) & \multicolumn{2}{|l|}{$33,75(19-51)$} & $33.15(20-50)$ & 0.7 \\
\hline BMI & \multicolumn{2}{|l|}{$25.3 \pm 1.4$} & $24.7 \pm 1.6$ & 0.67 \\
\hline Absolute lymphocytes (103/uL) & \multicolumn{2}{|l|}{$2.27 \pm 0.87$} & $2.92 \pm 6.5$ & 0.099 \\
\hline NLR & \multicolumn{2}{|l|}{$2.69 \pm 1.56$} & $1.37 \pm 0.53$ & $<0.001$ \\
\hline \multicolumn{3}{|l|}{ Tumor markers } & & \\
\hline $\mathrm{hCG}(\mathrm{mIU} / \mathrm{mL})$ & \multicolumn{2}{|c|}{$1877(1-113000)$} & & \\
\hline $\operatorname{AFP}(\mathrm{ng} / \mathrm{mL})$ & \multicolumn{2}{|c|}{$354(0.83-24622)$} & & \\
\hline $\mathrm{LDH}(\mathrm{U} / \mathrm{l})$ & \multicolumn{2}{|l|}{$380(15-3343)$} & & \\
\hline \multicolumn{5}{|l|}{ Pathology } \\
\hline Seminoma & \multicolumn{2}{|l|}{$50(62.5 \%)$} & & \\
\hline Non-seminoma & \multicolumn{2}{|l|}{$22(27.5 \%)$} & & \\
\hline Mixt & \multicolumn{2}{|l|}{$8(10 \%)$} & & \\
\hline \multicolumn{5}{|l|}{ Stage } \\
\hline IS & \multicolumn{2}{|l|}{$20(25 \%)$} & & \\
\hline IA & \multicolumn{2}{|l|}{$22(27.5 \%)$} & & \\
\hline IB & \multicolumn{2}{|l|}{$10(12.5 \%)$} & & \\
\hline II & \multicolumn{2}{|l|}{$19(23.75 \%)$} & & \\
\hline III & \multicolumn{2}{|l|}{$9(11.25 \%)$} & & \\
\hline Tumor size $(\mathrm{cm})$ & \multicolumn{2}{|l|}{$5.05 \pm 2.91$} & & \\
\hline Rete testis invasion & \multicolumn{2}{|l|}{$34(42.5 \%)$} & & \\
\hline Vasculo-limfatic invasion & \multicolumn{2}{|l|}{$39(48.75 \%)$} & & \\
\hline $\mathrm{N}+$ & \multicolumn{2}{|l|}{$20(25 \%)$} & & \\
\hline M1 (pulmonary) & \multicolumn{2}{|l|}{$6(7.5 \%)$} & & \\
\hline M1 (non-pulmonary) & \multicolumn{2}{|l|}{$3(3.75 \%)$} & & \\
\hline \multirow[t]{2}{*}{ Treatment following orchiectomy } & Surveillance & $33(41.25 \%)$ & & \\
\hline & Chemotherapy & 47 (58.75\%) & & \\
\hline
\end{tabular}

The mean age of the testicular cancer group was $33.75(19-51)$ years, while the mean age of the control group was $33.15(20$ - 50) years. No statistically significant differences were found between the two groups regarding age $(p=0.7)$ nor BMI $(p=0.67)$. Absolute neutrophils count was higher in the testicular cancer group (3.94 \pm 1.4 vs. $5.20 \pm 2.4 ; \mathrm{p}<0.001)$. While absolu- te lymphocyte count was higher in the control group, but these differences were not statistically significant $(2.92 \pm 6.5$ vs. $2.27 \pm 0.87 ; \mathrm{p}=$ $0.099)$. NLR was higher in testicular cancer group $(2.69 \pm 1.56$ vs. $1.37 \pm 0.53 ; \mathrm{p}<0.001)$, as shown in Fig [1]. After classifying by disease stage, NLR was significantly higher in those patients with a stage > I $(3.3 \pm 1.39$ vs. $2.28 \pm 1.55 ; \mathrm{p}=0.014)$. 


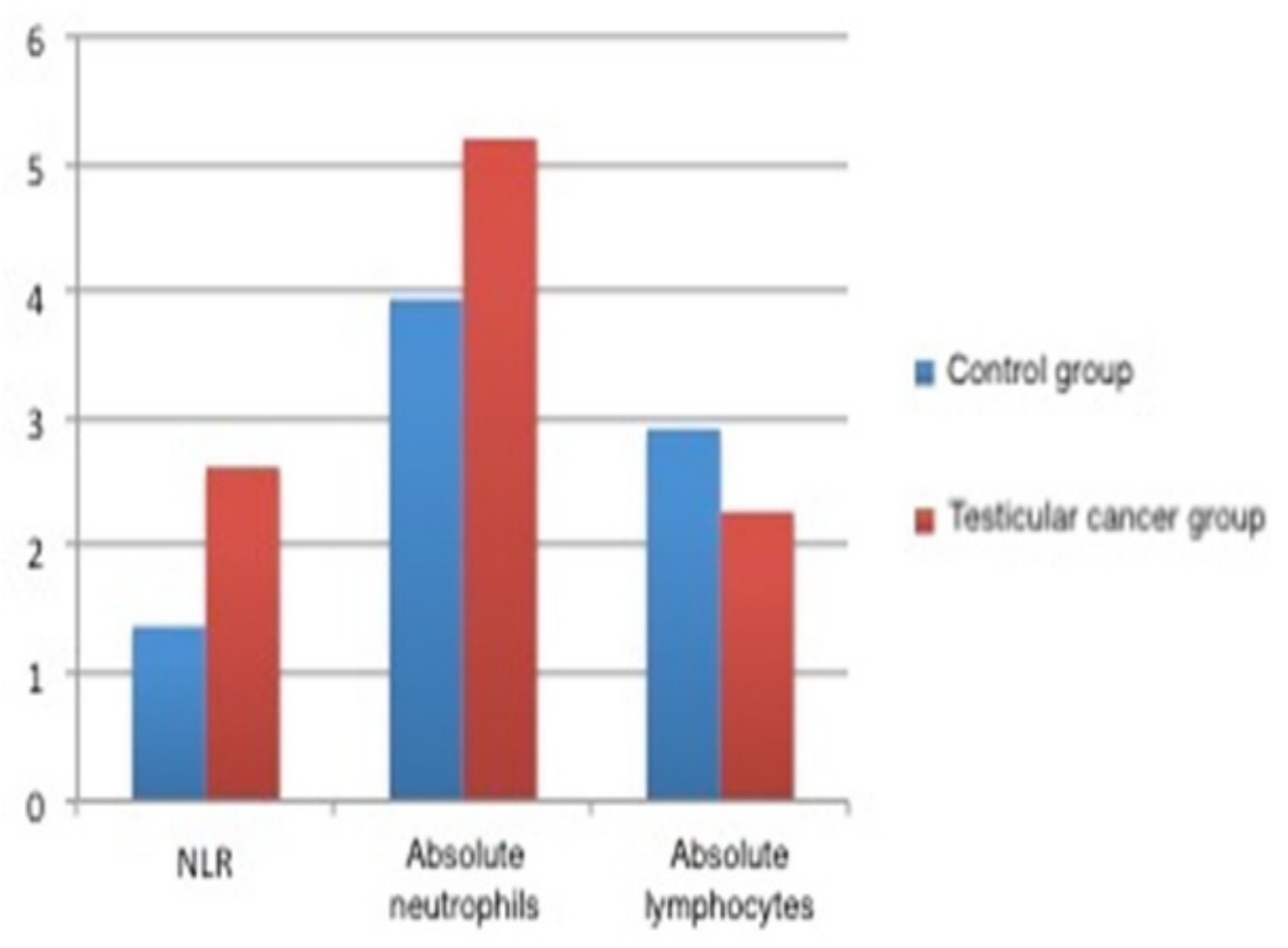

Fig. 1. Absolute neutrophils, absolute lymphocytes and NLR counts for the testicular cancer and the control groups

No correlation was observed between NLR and conventional pre-orchiectomy tumor markers
(AFP, hCG, and LDH) (r-value: 0.08, 0.06 and 0.09, respectively), as shown in Fig. [2].

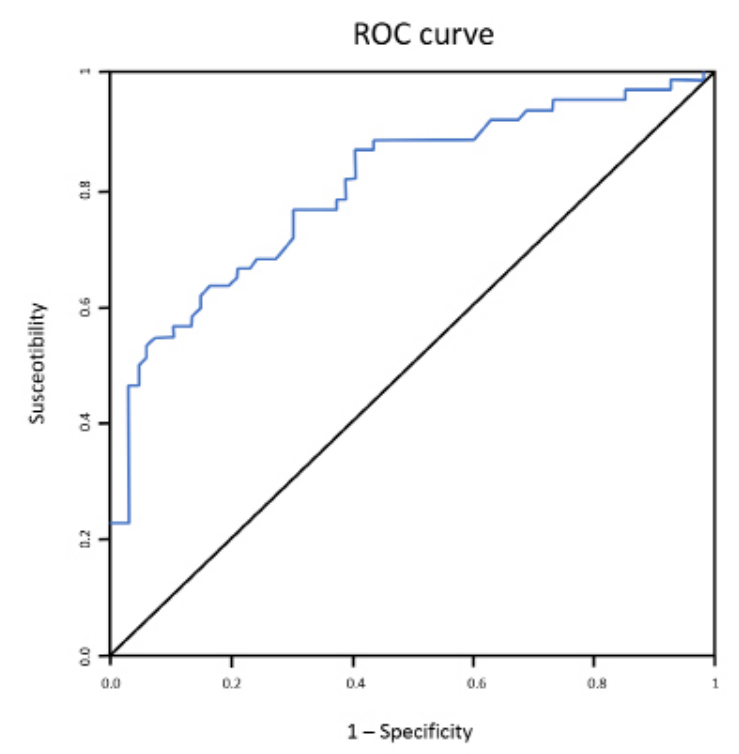

Fig. 2. ROC curve for testicular cancer diagnosis according to NLR 
NLR optimal cut-off value for testicular cancer diagnosis in our cohort was 2.2 (sensitivity: $76 \%$, specificity: $70 \%$, area under the curve: 0.802 ; IC 95\%: $0.663-$ 0.911), as shown in Fig. [3].
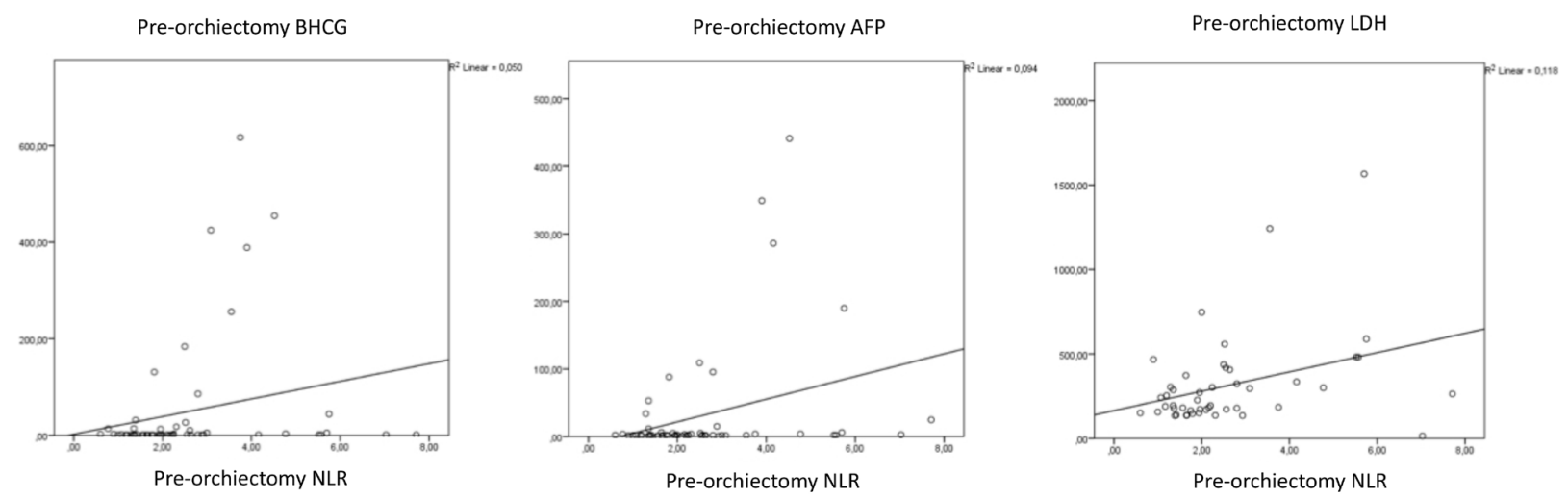

Fig. 3. Scatterplots showing no correlation between NLR and the other classical tumor markers

\section{Discussion}

In this report, we found that the NLR could be useful as an additional biomarker for testicular cancer diagnosis.

Previous reports have shown systemic inflammation to play a major role in cancer development. It has been reported to promote either healing or growth and stimulation of metastasis [8]. Indeed, relative neutrophilia increases the inflammatory markers release, including pro-angiogenic and growth factors, proteases and anti-apoptotic factors, thus favoring tumor growth, and progression $[25,26]$.

Such neutrophilia might be due to the stimulus produced by the release of myeloid growth factors in the context of a para-neoplastic syndrome $[27,28]$. On the other hand, neutrophilia could more likely be secondary to a non-specific inflammatory response, favored by the tissue destruction and subsequent cytokines release in the cancer context [29]. On the other side, the relative lymphopenia may reflect a smaller amount of CD4+ T-helper lymphocytes, leading to a suboptimal lymphocyte-mediated immune response against cancer [30]. Both mechanisms could act together contributing to the biological aggressiveness of cancer, its progression, and prognosis. been suggested, including the $\mathrm{C}$ reactive protein, the platelets or the leucocytes counts and the NLR [9].

Previous studies reported that the NLR is a poor prognostic factor in non-urological [14-17] and urological tumors [10-13]. In a recent metaanalysis, Wei et al. reported high NLR values after analyzing 17 studies including 3159 patients affected by urological tumors and concluded that NLR could be a prognostic biomarker in urological cancers [31]. Nevertheless, none studies on testicular cancer were included in their meta-analysis by the authors. We thought the present study trying to contribute to the gap in the literature about the topic, as the role of the NLR is not well established in testicular cancer. Our study compares the features of a cohort of patients with testicular cancer with a control group, and shows the potential role of the NLR in diagnosing testicular cancer. Only five studies have been previously published in the field.

Yuksel et al. first studied the relationship between testicular cancer and the NLR [18]. They retrospectively evaluated 36 patients with testicular cancer compared to 36 controls, concluding that the NLR could be a good complementary biomarker for the diagnosis of localized testicular cancer.

Several markers of systemic inflammation have 
Recently, Gokcen et al. showed similar results after comparing 39 testicular cancer patients with 82 controls [19]. Nevertheless, the authors failed to demonstrate a correlation between the NLR and the different stages of the disease. Our results partially agree with those previously reported by Yuksel and Gokcen. In our cohort, the NLR was also higher in the testicular cancer group compared to controls. However, we observed that higher NLR was associated with higher disease's stage at the diagnosis, which could provide additional useful information. We also noticed the absence of correlation between NLR and classical tumor markers, which could also be useful when facing challenging diagnostic situations with negative tumor markers. In our opinion, the larger sample size of our cohort could explain the previously exposed differences.

Few authors have previously studied the prognostic value of this biomarker for testicular cancer, with contradictory results [32-34]. Bolat et al. retrospectively evaluated the preoperative NLRs in a group of 53 patients with testicular cancer. They analyzed cancer-specific survival and progression-free survival without finding a significant relationship with the NLR [32]. Probably a low recurrence and death events occurrence in their cohort might prevent the reliable estimation of progression-free and cancer-specific survival.

On the other hand, Jankovic et al. studied in a retrospective series of 103 patients the link between the NLR and testicular cancer features. They reported that an NLR $\geq 4$ was observed in $>$ T1 pathological stage [33]. Furthermore, Fankhauser et al. retrospectively investigated the prognostic utility of several systemic inflammatory markers in 146 metastatic testicular cancer patients. The authors found that the leukocytes count, the neutrophils count, the systemic immuneinflammation index (calculated as Neutrophils $\mathrm{x}$ Platelets / Lymphocytes) and the NLR were independent predictors of shorter overall survival [34]. These are remarkable results, which should encourage us to further research on this topic.

In summary, in the present study we found the NLR to be higher in patients with testicular cancer compared to the control group, moreover, higher NLR was also associated with higher disease's stage at the diagnosis. Although testis are very accessible organs to explore, with a very good diagnostic method (testicular ultrasound) and there are other proven biomarkers, we believe that our results could add useful information to the diagnosis of testicular cancer. It can help in the diagnosis of doubtful cases such as those with microcalcifications in testicular ultrasound, and it gives an early information about the disease stage, allowing for an early diagnosis of the advanced disease and its treatment. Additionally, it is wildly accessible and a very cheap biomarker

Our study had some drawbacks. First, the retrospective design with inherent biases. Second, it was a single-center analysis with a small sample size. Also, a statistical power calculation was not carried out prior to the beginning of the study. Moreover, the heterogeneity of the sample maybe limited the reliability of our analysis. Our preliminary report has to be validated in larger cohorts, with subgroup analyses and considering potential confounders.

\section{Conclusions}

In the present study, NLR was higher in the testicular cancer group and patients with a higher stage at diagnosis. The optimal cut-off value for testicular cancer diagnosis was 2.2 in our cohort. Thus, NLR is a cheap and widely available biomarker, which could be useful in testicular cancer diagnosis in addition to other accepted tumor markers.

\section{Conflict of interest}

No funding source has been collaborated with our group for this manuscript's confection. This manuscript has not been published and is not under consideration for publication elsewhere. The authors report no conflict of interest. 


\section{References}

1. Albers P, Albrecht W, Algaba F, Bokemeyer C, Cohn-Cedermark G, Fizazi K, Horwich A, Laguna MP, Nicolai N OJ. EUA Guidelines on Testicular Cancer. Available from: http:// uroweb.org/wp-content/uploads/11-TesticularCancer_2017_web.pdf

2. La Vecchia C, Bosetti C, Lucchini F, Bertuccio P, Negri E, Boyle P, et al. Cancer mortality in Europe, 2000?2004, and an overview of trends since 1975. Ann Oncol [Internet]. 2010 Jun [cited 2017 Jul 2];21(6):1323-60. Available from: http://www.ncbi.nlm.nih.gov/pubmed/19948741

3. Siegel RL, Miller KD, Jemal A. Cancer statistics, 2016. CA Cancer J Clin [Internet]. 2016 Jan [cited 2019 Mar 26];66(1):7-30. Available from: http://doi.wiley.com/10.3322/caac.21332

4. Nigam M, Aschebrook-Kilfoy B, Shikanov $\mathrm{S}$, Eggener S. Increasing incidence of testicular cancer in the United States and Europe between 1992 and 2009. World J Urol [Internet]. 2015 May 17 [cited 2017 Jul 2];33(5):623-31. Available from: http://www.ncbi.nlm.nih.gov/ pubmed/25030752

5. Jemal A, Siegel R, Ward E, Hao Y, Xu J, Thun MJ. Cancer Statistics, 2009. CA Cancer J Clin [Internet]. 2009 Jul 1 [cited 2017 Jul 2];59(4):225-49. Available from: http://www. ncbi.nlm.nih.gov/pubmed/19474385

6. Rosen A, Jayram G, Drazer M, Eggener SE. Global Trends in Testicular Cancer Incidence and Mortality. Eur Urol [Internet]. 2011 Aug [cited 2017 Jul 2];60(2):374-9. Available from: http:// www.ncbi.nlm.nih.gov/pubmed/21612857

7. Medina-Rico M, López-Ramos H. [Testicular Cancer Epidemiology in Developing Countries. Review of the literature.]. Arch Esp Urol [Internet]. 2017 Jun [cited 2017 Jul 2];70(5):51323. Available from: http://www.ncbi.nlm.nih. gov/pubmed/28613204

8. Mantovani A, Allavena P, Sica A, Balkwill F. Cancer-related inflammation. Nature [Internet]. 2008 Jul 24 [cited 2017 Jun 15];454(7203):43644. Available from: http:/www.nature.com/ doifinder/10.1038/nature07205
9. Roxburgh CSD, Crozier JEM, Maxwell $\mathrm{F}$, Foulis AK, Brown J, McKee RF, et al. Comparison of tumour-based (Petersen Index) and inflammation-based (Glasgow Prognostic Score) scoring systems in patients undergoing curative resection for colon cancer. Br J Cancer [Internet]. 2009 Mar 10 [cited 2017 Jun 15];100(5):701-6. Available from: http://www.ncbi.nlm.nih.gov/ pubmed/19209171

10. Boissier R, Campagna J, Branger N, Karsenty $\mathrm{G}$, Lechevallier E. The prognostic value of the neutrophil-lymphocyte ratio in renal oncology: A review. Urol Oncol Semin Orig Investig [Internet]. 2017 Apr [cited 2017 Jun 15];35(4):135-41. Available from: http://www.ncbi.nlm.nih.gov/ pubmed/28233671

11. Boegemann $M$, Schlack $K$, Thomes $S$, Steinestel J, Rahbar K, Semjonow A, et al. The Role of the Neutrophil to Lymphocyte Ratio for Survival Outcomes in Patients with Metastatic Castration-Resistant Prostate Cancer Treated Abiraterone. Int J Mol Sci [Internet]. 2017 Feb 11 [cited 2017 Jun 15];18(2):380. Available from: http://www.mdpi.com/1422-0067/18/2/380

12. Li $X$, Ma $X$, Tang L, Wang $B$, Chen L, Zhang F, et al. Prognostic value of neutrophilto-lymphocyte ratio in urothelial carcinoma of the upper urinary tract and bladder: a systematic review and meta-analysis. Oncotarget [Internet]. 2017 Apr 27 [cited 2017 Jun 15]; Available from: http://www.oncotarget.com/fulltext/17467

13. Kasuga J, Kawahara T, Takamoto D, Fukui S, Tokita T, Tadenuma T, et al. Increased neutrophilto-lymphocyte ratio is associated with diseasespecific mortality in patients with penile cancer. BMC Cancer [Internet]. 2016 Dec 7 [cited 2017 Jun 15];16(1):396. Available from: http:// bmccancer.biomedcentral.com/articles/10.1186/ s12885-016-2443-6

14. He W, Wei M, Yang X, Chen B, Wu Q, Zheng E, et al. Do inflammatory markers predict prognosis in patients with synchronous colorectal cancer? Medicine (Baltimore) [Internet]. 2017 Apr [cited 2017 Jun 15];96(17):e6607. Available from: http://www.ncbi.nlm.nih.gov/pubmed/28445257 
15. Luo G, Liu C, Cheng H, Jin K, Guo M, Lu $\mathrm{Y}$, et al. Neutrophil-lymphocyte ratio predicts survival in pancreatic neuroendocrine tumors. Oncol Lett [Internet]. 2017 Apr 13 [cited 2017 Jun 15];13(4):2454-8. Available from: http:// www.spandidos-publications.com/10.3892/ ol.2017.5716

16. Takeuchi H, Kawanaka H, Fukuyama S, Kubo N, Hiroshige S, Yano T. Comparison of the prognostic values of preoperative inflammationbased parameters in patients with breast cancer. Coleman WB, editor. PLoS One [Internet]. 2017 May 10 [cited 2017 Jun 15];12(5):e0177137. Available from: http://dx.plos.org/10.1371/ journal.pone. 0177137

17. Gomez D, Farid S, Malik HZ, Young AL, Toogood GJ, Lodge JPA, et al. Preoperative Neutrophil-to-Lymphocyte Ratio as a Prognostic Predictor after Curative Resection for Hepatocellular Carcinoma. World J Surg [Internet]. 2008 Aug 14 [cited 2017 Jul 3];32(8):1757-62. Available from: http://www. ncbi.nlm.nih.gov/pubmed/18340479

18. Yuksel $\mathrm{OH}$, Verit $A$, Sahin A, Urkmez A, Uruc F. White blood cell counts and neutrophil to lymphocyte ratio in the diagnosis of testicular cancer: a simple secondary serum tumor marker. Int Braz J Urol [Internet]. [cited 2017 Jun 13];42(1):53-9. Available from: http://www. ncbi.nlm.nih.gov/pubmed/27136467

19. Gokcen K, Dundar G, Gulbahar H, Gokce G, Gultekin E. Can routine peripheral blood counts like neutrophil-to-lymphocyte ratio be beneficial in prediagnosis of testicular cancer and its stages? J Res Med Sci [Internet]. 2018 [cited 2019 Mar 26];23(1):64. Available from: http://www. jmsjournal.net/text.asp?2018/23/1/64/237591

20. Sobin LH, Compton CC. TNM seventh edition: What's new, what's changed. Cancer [Internet]. 2010 Nov 15 [cited 2017 Jun 15];116(22):5336-9. Available from: http://www. ncbi.nlm.nih.gov/pubmed/20665503

21. Warde P, Specht L, Horwich A, Oliver T, Panzarella T, Gospodarowicz M, et al. Prognostic Factors for Relapse in Stage I Seminoma
Managed by Surveillance: A Pooled Analysis. J Clin Oncol [Internet]. 2002 Nov 15 [cited 2017 Jun 15];20(22):4448-52. Available from: http:// www.ncbi.nlm.nih.gov/pubmed/12431967

22. Albers $P$, Siener R, Kliesch S, Weissbach L, Krege S, Sparwasser C, et al. Risk Factors for Relapse in Clinical Stage I Nonseminomatous Testicular Germ Cell Tumors: Results of the German Testicular Cancer Study Group Trial. J Clin Oncol [Internet]. 2003 Apr 15 [cited 2017 Jun 15];21(8):1505-12. Available from: http:// www.ncbi.nlm.nih.gov/pubmed/12697874

23. Demirer Z, Güragac A, Uguz S, Uslu AU, Zor M. RE: White blood cell counts and neutrophil to lymphocyte ratio in the diagnosis of testicular cancer: a simple secondary serum tumor marker. Int Braz J Urol [Internet]. [cited 2017 Jul 2];42(6):1251-2. Available from: http://www. ncbi.nlm.nih.gov/pubmed/27813388

24. Fayyad U, Irani K. Multi Interval Discretization of Continuous Valued Attributes for Classification Learning. In: Proceedings of the International Joint Conference. 1993. 25. Jabłońska E, Kiluk M, Markiewicz W, Piotrowski L, Grabowska Z, Jabłoński J. TNF-alpha, IL-6 and their soluble receptor serum levels and secretion by neutrophils in cancer patients. Arch Immunol Ther Exp (Warsz) [Internet]. 2001 [cited 2017 Jun 15];49(1):63-9. Available from: http://www. ncbi.nlm.nih.gov/pubmed/11266093

26. McCourt M, Wang JH, Sookhai S, Redmond HP. Proinflammatory mediators stimulate neutrophil-directed angiogenesis. Arch Surg [Internet]. 1999 Dec [cited 2017 Jun 15];134(12):1325-31; discussion 1331-2. Available from: http://www.ncbi.nlm.nih.gov/ pubmed/10593330

27. Tamhane UU, Aneja S, Montgomery D, Rogers E-K, Eagle KA, Gurm HS. Association Between Admission Neutrophil to Lymphocyte Ratio and Outcomes in Patients With Acute Coronary Syndrome. Am J Cardiol [Internet]. 2008 Sep 15 [cited 2017 Jun 15];102(6):653-7. Available from: http://www.ncbi.nlm.nih.gov/ pubmed/18773982 
28. Kasuga I, Makino S, Kiyokawa H, Katoh H, Ebihara Y, Ohyashiki K. Tumor-related leukocytosis is linked with poor prognosis in patients with lung carcinoma. Cancer [Internet]. 2001 Nov 1 [cited 2017 Jul 3];92(9):2399-405. Available from: http://www.ncbi.nlm.nih.gov/ pubmed/11745296

29. Singel KL, Segal BH. Neutrophils in the tumor microenvironment: trying to heal the wound that cannot heal. Immunol Rev [Internet]. 2016 Sep [cited 2017 Jul 3];273(1):329-43. Available from: http:/www.ncbi.nlm.nih.gov/ pubmed/27558344

30. Viers BR, Boorjian SA, Frank I, Tarrell RF, Thapa P, Karnes RJ, et al. Pretreatment neutrophil-to-lymphocyte ratio is associated with advanced pathologic tumor stage and increased cancer-specific mortality among patients with urothelial carcinoma of the bladder undergoing radical cystectomy. Eur Urol [Internet]. 2014 Dec [cited 2017 Jun 15];66(6):1157-64. Available from: http://linkinghub.elsevier.com/retrieve/pii/ S0302283814001717

31. Wei Y, Jiang Y-Z, Qian W-H. Prognostic role of NLR in urinary cancers: a meta-analysis. Gao J-X, editor. PLoS One [Internet]. 2014 Mar 18 [cited 2017 Jun 15];9(3):e92079. Available from: http://dx.plos.org/10.1371/journal.pone.0092079 32. Bolat D, Aydogdu O, Polat S, Yarimoglu S, Bozkurt IH, Yonguc T, et al. Predictive value of preoperative neutrophil-to-lymphocyte ratio on the prognosis of germ cell testicular tumors. T?rk ?roloji Dergisi/Turkish J Urol [Internet]. 2017 Feb 21 [cited 2017 Jun 13];43(1):55-61. Available from: http://www.ncbi.nlm.nih.gov/ pubmed/28270952

33. Jankovich M, Jankovichova T, Ondrus D, Breza J. Neutrophil-to-lymphocyte ratio as a predictor of preoperative tumor staging in testicular germ cell tumors. Bratisl Lek Listy [Internet]. 2017 [cited 2017 Nov 29];118(9):510-2. Available from: http://www.elis.sk/index.php?page=shop. product_details\&flypage $=$ flypage.tpl\&product $\mathrm{id}=5423$ \&category_id=135\&option $=$ com virtuemart

34. Fankhauser CD, Sander S, Roth L, Gross O, Eberli D, Sulser T, et al. Systemic inflammatory markers have independent prognostic value in patients with metastatic testicular germ cell tumours undergoing first-line chemotherapy. $\mathrm{Br} \mathrm{J}$ Cancer [Internet]. 2018;118(6):825-30. Available from: http://dx.doi.org/10.1038/bjc.2017.467 